\title{
Towards an Aesthetic of Feminine Malice? The Visual Proposals From Female Pop Artists
}

\author{
Laura Triviño Cabrera \\ University of Malaga, Malaga, Spain
}

\begin{abstract}
This proposal aims to highlight problems surrounding the ethics-aesthetics relationship projected by female pop singers in their music videos and the formulation of new models of femininity. However, it is possible these models never existed and this is a reformulation of female roles and stereotypes invented by patriarchy. Spanish philosopher Amelia Valcárcel spoke of how women had a "right to malice”, a concept appropriated by men, while women were excluded from it and relegated to the field of kindness and sacrifice. Based on this premise, could it be stated that the image of women in modern culture prefers to use malice to attain equality? In the 2010 music video for Telephone, Lady Gaga and Beyoncé appeared as murderers who killed some diner customers. Seduction, arrogance and indifference were intertwined using postmodern aesthetics with nods to pin-up style. So do women need to take up malice in order to feel more self-confident and prepared to play a dominant role in society? Would they be repeating the traditional male model characterised by the use of violence? It is here that we would have to reformulate Lipovetsky's "third woman” model, which claims that women aim to attain equality by repeating old female stereotypes that present them as the "fair sex” or old male stereotypes, adopting Valcárcel's "right to malice”. And more importantly, what kind of message is this sending out to people, particularly to teenagers and young adults who are hugely influenced by the media. As a teacher and philosopher, I am concerned about the kinds of values being promoted by pop music culture and whether they are improving or harming society. Could new models of femininity change the way in which younger generations relate to one another? Could they be feeding into the "crisis of values" that characterises post-modern society? During a class discussion, several female students commented that the singer Beyoncé was a role model for women: strong, self-confident, and an advocate for those same rights for women; a mirror to hold up to oneself. So what kind of image is Beyoncé projecting in her videos? Does she truly break away from old feminine roles and stereotypes?
\end{abstract}

Keywords: aesthetics of female malice, female pop artists, “third woman”, Lipovetsky, "right to malice”, Valcárcel, videoclip, values, post-modern society, gender stereotypes and roles

\section{The Ethics-Aesthetics Conundrum: Which Values Are Female Pop Singers Projecting in Their Videos?}

This research is grounded in the need to transfer the analysis of media-and how they can influence the promotion of certain values-into the field of education. If our university students are preparing to become

Laura Triviño Cabrera, Ph.D., lecturer, University of Malaga, Spain.

Correspondence concerning this article should be addressed to Louis Pasteur Boulevard, Faculty of Education Sciences, Teatinos Campus, Malaga, 29071, Spain. 
teachers to future generations, they must be aware of the importance of image and of how aesthetics can determine ethics. Hence, this article examines the aesthetics of malice since, in our image-driven society, aesthetics projects values and counter-values that inevitably feed into ethics. It could even be said that,

ethics and aesthetics, are one and the same thing. Both are ineffable; they cannot be put into words, into the words of meaningful language, since they express something higher, which cannot be expressed in that language. (Valcárcel, 1998, pp. 196-197)

Given that such matters can span many different realms, this article focuses on the way in which the image projected by female pop singers through their music videos can inspire a new ethics of femininity. This involves superimposing the aesthetics of femininity onto the ethics of femininity, which will probably flag up more points of divergence than similarities in the already complex world of thought and the feminist movement.

By elevating the values of wellbeing, leisure, and individual happiness to a previously unknown scale, the age of consumerism has discredited the underlying sacrificial ideology in the model of the perfect housewife. The new culture, centred on pleasure and sex, recreation, and free individual choice, has devalued a mode of feminine living that looks more towards the family than to itself; it has legitimated the desire to live by and for oneself to a greater extent. [...]. Revolution of needs, sexual revolution...; the age of mass consumption is not only characterised by the proliferation of products, but also by the profusion of signs and references for sex. (Lipovetsky, 2009, pp. 210-211)

If, according to Amelia Valcárcel (2004), fashion is a phenomenon that allows customs and values to be aestheticised, one could say that music videos contribute in the same way to proposing how women should act in society; how a new feminist ethic is configured, given that, in part, female pop singers are responsible for showing the latest designer trends and, therefore, clothing is capable of transmitting behaviours and values.

Clearly, as indicated by Rivière (2009), a pop singer might act as an "ambassador for values and social models and a driver of opinion in all terrains-from aesthetics to ethics. They can also be drivers of social change” (cited in Busquet, 2012, p. 19). That capacity to generate values (or counter-values) even leads some authors such as Morín (1972, p. 59, cit. in Busquet, 2012, p. 17) to talk about the creation of a religion around a certain artist.

Hence, one of the aims of this paper is to recover the idea developed in The Feminine Mystique project in the US around the images of woman regarding how models of femininity established in the media have an impact on the women who consume that popular culture (Hollows, 2000, p. 17).

It is true that audiovisual messages do not always reach people in the same way, nor are they always interpreted in the same way. Proof of this can be found in the survey carried out as part of this study with students enrolled on the Primary Education Teacher Training Degree, questioning them about the values and image projected by Lady Gaga and Beyoncé in the music video for Telephone (2010). Close to 70\% of these future teachers stated that they did not observe any values and that the image of both singers did not reflect a female role model to be aspired to. So, does that mean that such an aesthetic of malice would not influence them?

\section{Strategies to Achieve Equality Between Women and Men: Recourse to Malice}

"Evil" has been one of the most widely discussed and controversial concepts in the history of thought. Its definition implies positioning ourselves in relation to the obsessive contemplation of the world as a series of dichotomies: good/evil, nature/culture, man/woman, reason/superstition, wisdom/ignorance, light/darkness, etc. 
Raising the very question of malice acknowledges concern for the problems of our world, the existence of human suffering at the hands of our peers, and how this ties in with the paradoxical line of thought that if God is good, could evil have been created by him? This led Leibniz, in his Essais de Théodicee sur la Bonté de Dieu, la liberté de l'homme et l'origine du mal, to propose a classification based on three types of evil: metaphysical evil, physical evil, and moral evil. This article is interested in the third type of evil: Moral evil that is constituted by sin and which leads to the existence of suffering in our world (Ortiz, pp. 153-154).

But can evil and goodness be gender specific? If viewed in terms of pairs of opposites, then yes it could. Women would assimilate the negative connotations. However, if we focus on specifying the terms, there would be a differential nuance between evil and malice, in the opinion of Román (2004): whereas evil alludes to the concept in itself, which can be defined as an absence of good, malice requires an act in order to be so.

When faced with good and evil, the feminine sex is evil by nature. For Amelia Valcárcel, the Judeo-Christian tradition had attributed the creation of evil to the first woman, which meant that all women were required to obey higher moral standards than the rest, leaving malice, therefore, as the exclusive right of men.

If the world strikes its moral balance, leaving it to just one gender to perpetrate all the evils it can, while the other gender is responsible for caring, this presents a limited, gravely false worldview with certain elements of the ridiculous. What is good? What is caring, safeguarding and protecting, or doing whatever you want? So then let's all do what we want and see how long this phenomenon lasts. Or let's all set to caring, since the statement has a flip side. I don't want to be excellent, or special. I merely reclaim my right to not be excellent, according to that model. In that sense, I defend the right to malice, a malice that would twist the current direction of the world. (Valcárcel, 2004)

If, as Kate Millet points out in Sexual Politics, the patriarchy is configured around a system that pursues male dominance over women, Valcárcel (1991, pp. 164-165) proposes that if women want to break that dominance, they will have to position themselves at the same level as the laws that govern male oppression. So, if the prevalent universal rules of conduct have been established by the patriarchal system, vengeance, violence, competitiveness... in short, evil, women must attain those universals imposed by the patriarchy in order to achieve the goodness of equality and leave submission behind.

Looking at the majority of music videos made by female pop singers, the aesthetics are inspired by the feminism of equality, as understood by Valcárcel, since women have no problem carrying out acts of malice. Therefore, if they want to behave in the same way as men, they will have to take on traditional male stereotypes: Men must be strong, independent, violent, insensitive, aggressive, and self-assured. But one essential characteristic must remain in women who respond to those traditional feminine stereotypes: Women must promote their beauty (sexual).

Yet, would that not simply be repeating the tired old archetype of the "femme fatal"?

which comes from the male imagination, desirable, attractive, wicked and dangerous for man. Ultimately, an erotic figure with a high sexual charge [...].They are a type of women thought up by men, beautiful and perverse, who dominate the male until they rob him of his patriarchal power. This means that there is a loss of masculinity in modern terms, or, on the contrary, that femininity has forced man to question himself, how he defines himself, and using which parameters. (Román, 2004, p. 16)

The problem lies in the question of which type of malice would be required to avoid running the risk of falling into the archetype of "femme fatal". The cases of Lady Gaga, Beyoncé, Christina Aguilera, Taylor Swift, Katy Perry and Rihanna might fall into this category, with certain nuances. Firstly, all these female pop singers have opted for a new representation of women: 
A "new" woman, independent, working, more in line with social tendencies and moving away from the tendencies that marked women as housewives, mothers, and wives. In spite of these new trends, beauty and seduction are still constants in female representation in advertising. (Hidalgo-Marí, 2015, p. 407, cited in Peña-Martín \& Frabetti, 1990)

Hidalgo-Marí (2015) provides some useful guidelines regarding the different aesthetics of this new "femme fatal" seen in the music videos of female pop singers. She talks about the rebellious femme fatal as,

one who does not abide by established rules. She is still, as in the previous case, an independent and provocative woman, but in this case, we catch a glimpse of a certain rebelliousness. She does not abide by the rules and is usually seen bearing weapons $[\ldots]$ or alluding to forbidden games [...]. This rebellious femme fatal contains the classic reflection of the transgressive woman, one who moves away from social uniformity and searches, using her own means, for success or the attainment of her goals. (2015, p. 410)

Following this definition, the music videos of Lady Gaga and Beyoncé, Christina Aguilera, Taylor Swift, Rihanna, and Katy Perry, discussed below, would fall into this category of femme fatal since "the femme fatal is the protagonist of the story; She takes on the role of subject and adopts a series of traits that are usually considered 'masculine' such as violence, autonomy, ambition, or hunger for power” (Cruzado: 3). Along these lines, Aguayo raises the question: "Who is the truly dangerous, evil, malign woman? She who takes on roles considered traditionally masculine” (Aguayo, 2012, p. 99).

So, are we dealing with a femme fatale or a woman who advocates equality and defends her right to malice? Should we reject Lipovetsky's notion that the link between feminine beauty and malice is disappearing?

In contrast to men, considered equal subjects, individuals, women are conceived of as being identical, indiscernible in the words of Celia Amorós (2007, p. 87). Women, as identical beings, would be considered, in the opinion of Amelia Valcárcel, "obliging, nice, pacific, eager to please, timid, fearful, cowardly, hypocritical, artful, even cunning when it comes to it... all characteristics commonly aligned to those who have no means of offending or defending themselves against the offences of others” (Valcárcel, 2008, p. 102). And she goes on to say, "at most, and only very recently, women are gaining the right to get angry, although always in a measured way, naturally” (Valcárcel, 2008, p. 102).

Female pop singers who, aesthetically speaking, might follow the feminism of equality, are identical in their qualities: strong, independent, astute, sexy... and they fall into the patriarchal culture, since their audience, their public compares them to one another. Women are prevented from competing with men in the cultural industry.

The perspective grid is like this: Each woman is not compared to a man of her type (a peer in strict terms); instead, women are compared to one another. This woman with that one, so a single representation of their gender prevails: "I want this one, I don't want that one”, “I like it or I don't like it”, as if they can only be measured against one another. This even entails another implicit notion: We only compare them with one another, and they only compare themselves with one another... in order to present themselves to our divine compliance, which is where they acquire the capacity to shine, the capacity for individuality. (Valcárcel, 2008, pp. 112-113)

This leads audiences themselves to determine which singers are role models and which are not. The singer Miley Cyrus (former role model as a "Disney girl") questions: Why can Taylor Swift be a role model for teenagers, in spite of the violence shown in her latest music videos; and yet Cyrus is not, given the sexual content of her videos and performances? Is the perception, therefore, that sexuality is a bad example, but aggressiveness is not? When I asked my students, they were more shocked by and unwilling to accept the 
sexual overtones and "pornographic" clothing of singers than the violence, murder, and aggressiveness they portray. This is why there is reticence to what Valcárcel refers to as the "law of attraction":

I feel that in order to understand a body as feminine, it has to appear or almost border on a pornographic presentation, because otherwise it is not understood as feminine. [...] I believe that this is a rather fun hypothesis and it is relatively easy to verify the correlation between greater freedom and more exposure of the body. (2010, pp. 92-94)

However, there is one aspect that must also be taken into account. We have seen how singers take on a visual persona of malice towards men, but what happens if they are malicious towards their own sex? In the case of Telephone, there is an allusion to a lesbian femme fatal. In prison, Lady Gaga portrays sexual attraction towards an inmate who could physically correspond to the masculine image. But there is also partnership between women. Beyoncé picks Lady Gaga up from prison and they both embark on a journey that leads them to commit multiple murder. The video finishes with a shot of Gaga and Beyoncé holding hands and a final shot, showing the feminine symbol.

\footnotetext{
Woman has overcome the barrier of male control and she shows herself to be a fully independent woman, self-assured, and totally separate from need or male control. The representation of women who interact affectionately with other women or who display sexual attraction towards other women represents a new woman who, firstly, is a fully independent being, and secondly, continues with the representation of temptation and seduction, in this case, through relations with other women. We see, therefore, that this representation of the femme fatal affirms that man is no longer a necessary subject in the modus operandi of the femme fatal, since she can persuasively influence other women. (Hidalgo-Marí, 2015, pp. 413-414)
}

In this respect, in the video for Bad Blood (2015) by Taylor Swift, only at the start of the video do we see a battle between visible women who are taking on mass-produced males, identical with no individuality, all dressed the same, in a grey suit, and wearing a mask. However, this possible feminine alliance against men comes to an end when one of them, the singer Selena Gómez, betrays Swift and pushes her out the window. And so we return once more to the "stereotypical definition" that women are bad for other women.

Lady Gaga and Beyoncé are angry. Firstly, we should point out that this video is a follow-up to Paparazzi (2009), in which Lady Gaga murders her partner by poisoning him as an act of revenge, since he tried to kill her by pushing her of a balcony. Gaga, in a wheelchair, takes control of her life and plans to punish her lover, who is unaware of Gaga's intentions and believes that she does not remember what happened. Lady Gaga has the right to be angry and, therefore, has a right to malice. Vengeance is an act that brings more damage than rewards to humanity in general. It has been a valuable quality when attributed to the male sex but is condemnable when perpetrated by a woman because, as Engels establishes, "what for women is a crime with grave legal and social consequences, is considered highly honourable for men, or at most a slight moral stain which is worn with pride" (Cited in Puleo, 1997, p. 10).

Now it is being claimed by women as well. Hence, this second video follows along the same lines. In this case, Beyoncé seeks revenge on her partner, poisoning him in an American roadside diner when he does not show the slightest interest in her and treats her contempt. Here it is worth making brief mention of the video made by Lilly Allen for Smile, in which the singer slips laxatives into her partner's coffee to get revenge for his betrayal (although she also hires a gang to beat him up and wreck his house). Poisoning and revenge have been a duo often attributed to the feminine sex. It is also a visible resource in the duet by Mika and Ariana Grande, Popular Song, in an atmosphere reminiscent of Harry Potter, where both singers are wizards who decide to wreak their revenge on classmates who bullied them. Having made their classmates disappear, and when Mika 
thinks that they have accomplished their revenge, Ariana Grande betrays him and finishes him off, since he also teased her.

The music video for Telephone raises a whole host of conundrums that could be discussed with university students. Hence, this video was chosen as the subject of a survey that would reflect the impressions of the students after watching it. In this video, Lady Gaga gets out of prison and, together with Beyoncé, enters an American roadside diner where the two of them proceed to poison all the diners' food. As a result, they poison every person having lunch at the restaurant: women, men, and a dog. However, the students seem to miss this detail. The majority of students explained that they committed murder out of revenge towards men who had behaved badly towards them.

In terms of values, the students highlighted the strength and defence of women against men. But what they emphasise the most and disapprove of is how the singers portray themselves as sexual objects. This is underscored much more as a counter-value than the murders and violence contained in the video. Therefore, beauty and sexuality have a greater impact than violence and murder.

This music video by Beyoncé and Lady Gaga marks a turning point in terms of reflecting a new aesthetic of femininity. To begin with, it takes us inside a women's prison, an invisible terrain for audiences, used to relating prison more with masculinity.

Secondly, it is important to bear in mind the contradictions of the "pin up" aesthetic used by Beyoncé in the video. "Pin up" can be taken to be:

a new style of beauty, the pin-up [...]. Stylised, healthy, smiling, there is nothing diabolical about the pin-up; She resembles a flirtatious sexy doll more than a praying mantis. (Lipovetsky, 2009, p. 160)

Taking on board this definition, se see that the aesthetic portrayed by Beyoncé does not correspond with her ethics. She snarls and grimaces, casting aside the friendly persona of the traditional pin-up.

As for Lady Gaga, her look is cyborgesque (Haraway, 1984), when she uses different types of telephones as hair accessories. Might Lady Gaga be in favour of cyber feminism? In other words, of how technology might allow for the emancipation of women from male dominance?

The importance of the narrative discourse of this video is that there is no reason whatsoever to kill off people who are having a quiet lunch in one of those typical American roadside diners. Paradoxically, they die at the hands of two women who then begin dancing whilst wearing costumes made from the stars and stripes flag. All highly patriotic.

Hence, we can see the existence of a female malice, of the image of two strong women, with no compassion or empathy, self-assured and working in partnership. Characteristics traditionally attributed to men, with the exception of one aspect: the exploitation of their beauty, their condition as sex object, and the excessive make-up seen in the image of all female pop singers.

The singer Rihanna, in her video for Bitch, Better Have My Money (2015), is an exponent of this category. This video takes a step further towards an aesthetic of feminine malice. The image she projects as a woman would not be socially acceptable, and the fact that she appears covered in blood in the last few scenes continues to reinforce the link between women and vampirism or ties to the devil. The main plot revolves around three women who kidnap and torture an upper class woman for the million-dollar ransom they are demanding from a husband who ignores the demands of the sinister and disturbing Rihanna. Finally we see how the husband, whilst his wife is kidnapped, gets drunk, takes drugs, and has sex with other women. Finally, Rihanna, when 
she does not get the ransom, decides to tie him up and kill him with a knife and a saw. The video finishes with an image of Rihanna covered in blood and sitting, naked, in a suitcase stuffed with dollars. This video has created a great deal of controversy, but many people defend the role played by Rihanna: If men can do it why cannot women be perverse and blood lusting? It comes back to the same thing. Malice is a necessary counter-value to achieve equality.

In the case of Christina Aguilera, she might also fit in with the archetype of the rebellious femme fatal but also the dominant femme fatal (Hidalgo-Marí, 2015, pp. 408-409) who turns men into playthings through sensuality and eroticism. In her video for Your Body (2012), she once again brings into playing the relationship between feminine beauty and malice. Aguilera plays the role of a voluptuous, trashy, brash woman who uses her charms to kill three men in three different ways: a car bomb whilst her lover sleeps; stabbing one in the toilets of a bar; and beating up a third man in a motel room. Blood is replaced by pink smoke from the explosion, in the first case, pastel green paint in the second, and pink streamers in the third murder. The video also contains an ironic announcement at the start that "no men were harmed in the making of this video".

Aguilera herself wears a necklace with the words "Rich Bitch" that insult her as a woman. What is interesting in this case is what has led Aguilera to murder her lovers. There is no free and independent decision made by her. It simply occurs because she sees a male psychic on television telling her she will be a murderer today. This leads us to deduce once more that there is no interest whatsoever in showing why women might kill, as was the case with Gaga and Beyoncé.

So it seems that female malice is unavoidable; it is within women because of Eve's original sin, and it will be passed onto all women who live in this world, freeing those who act according to the dictates of the patriarchal system, in other words, as an "angel of the home", excellent and submissive mothers and women kept shut away in the domestic realm. And this is the message we can ascertain from Taylor Swift's video for Black Space. Swift shows us the story of a refined young girl from the upper classes who lives in isolation in a mansion in the midst of beautiful gardens, waiting for her beloved to arrive in a luxury car. All goes well until Swift begins to suspect her lover might be cheating and lying to her. At this point, the young girl undergoes a transformation, acting aggressively, destroying the portrait of her beloved that she had painted, shredding his clothes and throwing them out the window, offering up her revenge, inspired by the figure of Eve. Swift offers her lover a poisoned apple, which he spits out in one of the scenes. Finally, Swift wrecks his car and he flees from the mansion in terror. The next shot shows us a new lover for Swift, or perhaps a new victim who once again arrives in a luxury car. This music video reflects the singer's actual love life, famous for writing lyrics into which she pours all her rage following break-ups. With that image, Swift is putting her ironic slant on the press's projection of her as a neurotic woman, flagging up the traditional stereotype of the wicked woman sickened by hysteria. However, Swift might also correspond to the archetype of the "femme fatal who evokes luxury and power" [...] "surrounded by luxurious items that endow her with power and elegance" (Hidalgo-Marí, 2015, pp. 412-413).

Yet, feminine malice is extrapolated to the screen, and these female singers perpetuate that same aesthetic in their real lives. In the case of Taylor Swift, she has even been accused of using the feminist slogan to increase her fame and fortune, branding her a perverse woman. And once again, feminine malice is linked with competitiveness and a drive for success, aspects that, when achieved by men, are not related with the concept of evil or ill doing. 
Swift has to be the person with the prettiest friends, the biggest records, the most popular and successful and groan worthily obvious boyfriend. (...) And watching her collect best friends during a moment in history when womanhood is finally beginning to feel valued does not only feel uncomfortable—it feels evil. (Evans, 2015, cited in Novo, 2015)

Therefore, Taylor Swift performs two ethical strands in the role of Eve (Ballester, 2013, p. 451): the innocent and passive "Eve" waiting for her "Adam" in a heavenly place surrounded by gardens and luxury; and the sinning malicious "Eve" who leads "Adam" to his downfall.

However, reflecting on our own world, we must return to the defence of women regarding this possible female malice originated by Eve provided by the philosopher Agrippa Von Nettesheim, declaring, «women are more chaste and benevolent, murder and war are usually characteristic of men» (Cited in Puleo, 1997, p. 167).

Finally, we shall look at the music video Katy Perry made for Dark horse (2014). Taking on the role of a bloodthirsty "Cleopatra", she projects arrogance, cruelty, and egomania. She even displays an obsession with luxury when she eats the jewels offered to her. Not one ounce of empathy, of consolation for the people she exploits or turns into animals or sand through sorcery. She creates a negative image for one of the few women in History who have made it into school textbooks and have played a governing role in society.

\section{A Portrayal of Feminine Benignity Is Also Possible: The Cases of Alicia Keys, Jennifer López and Katy Perry}

However, women can do away with the egotism, malice, imbalance and the anomaly that characterises them if they decide to follow the path of maternity and play the role to which they have been born and should be destined: the "good mother" (Ortega, 2015, p. 92).

Therefore, to conclude, we will examine that other vision, opposed to feminine malice, looking at female pop singers or music videos that put forward visual proposals based around feminine benignity. One of these is Alicia Keys, one of the most important singers in infusing values and the advocacy of equality between women and men (see Girl on Fire).

Both Jennifer López and Alicia Keys take on the role of mother-heroines, whose most significant deed involves helping a child. It is at this time when women can, according to Christian interpretation, cast off the sin of Eve and take on the goodness of the Virgin Mary. Yet feminine goodness could also be interpreted as a mechanism for controlling women (Hierro, 1992, p. 170). In the case of Jennifer López, in her video for Do it well (2007), she enters a club, taking on anyone who stands in her way, and fighting them with self-defence techniques. The audience does not know why she is acting in this way until the end of the music video and we see how López rescues a little boy who is being exploited in the kitchen of this high-end club.

As for Alicia Keys, in Try sleeping with a broken heart (2009), she plays the role of a heroine whose main heroic deed is to bring a little girl's dog back to life after it has been run over by a car in the road. There are several significant aspects suggesting that this music video offers an authentic deconstruction of the figure of the witch. First and foremost, we must remember that the concept of a "hero" is thought of as masculine. Only fairly recently, women have also begun to be heroines, but this is the result of a gradual evolution. The heroine was previously the "good witch" who appeared in order to counteract the role of "ad witch".

Keys also dressed in colours that hark back to the figure of the witch, black and purple, which in this latter case could be a nod to the feminist movement. However, she does not wear a cape, and her clothing is more contemporary, elegant and fashionable, with a jacket and black leather boots. Keys begins to distance herself from the role of witch since witches are usually older women who are able to fly and kill, and who use children 
and animals to prepare their potions (Araiza, 2008, pp. 70-71). According to Celtic and Slav mythology, witches are ugly and evil because they are fallen angels, losing their beauty and goodness as a diabolical punishment (Manzano, pp. 3-4). In the video, Keys represents a beautiful sweet woman, who can fly and who saves the life of an animal and helps a little girl. But there is one suspicious element: She is incapable of love. In one of the scenes, we see a man for whom Keys might have feelings, but when she puts her hand out, the man's skin seems to disintegrate. The solitude of the heroine stands in contrast to the hero, who always has a girl waiting for him and with whom he has some kind of a relationship. Keys, just like witches and fairies, will have to remain alone, sacrificing herself for others and living only to do good and care, a "being-for-others". And here we return once again to the idea of the role designated as "feminine" (Moreno, 2011, p. 323).

Finally, Katy Perry, in her video for Fireworks (2010), also shows a similar aesthetic to that of Keys, with purple tones even used in her hair. Perry produces fireworks that allow her to change the conflictive and problematic lives led by some of the people in the video: a boy and girl who are suffering because of their parents' fighting; a teenage girl who has a complex about her weight; a young man who is ashamed to admit his homosexuality; a little girl suffering from cancer.

It is precisely this feminine benignity projected by Keys, López and Perry that chimes with the characteristics attributed to women who could improve society.

For some years now, there has been a new type of discourse that characteristically celebrates the specificity of feminine power within organisations. Women who carry out management duties tend to opt for a more "democratic" model of management. They act in a more collegiate way than men, and they take the human dimension of problems more into account. A will to share power, the drive to value people, sensitivity in interpersonal relations: Perhaps this would be the feminine conjugation of management. We are witnessing the construction of a new myth, grounded in the idea that women will humanise a company, create more harmonious and satisfying workplaces that are less autocratic and more communicative. Here, what is most interesting is the fact that the myth is being created on the basis of qualities traditionally attributed to women, in other words sensitivity, intuition, concern for others, people orientation. (Lipovetsky, 2009, pp. 252-253)

Hence, Keys, López, and Perry (in these specific music videos) might correspond to that "third woman" signalled by the postmodern philosopher Lipovetsky, to define women in the 20th Century, defined as a new type of woman,

Who wants everything except the blurring of her femininity. The time has come to deny the aesthetics of difference no longer, but rather to reaffirm identities. Women want to behave in the same way as men, but that does not mean they want to resemble them. They denounce their exclusion from the spheres of power, their double working day, the wage inequality, but in general they do not reject as vehemently the aesthetic role attributed to them. In the present day, the demand for equality has been reconciled with the defence of aesthetic difference. (Lipovetsky, 2009, p. 182)

\section{Conclusions}

So, does the new feminine aesthetic of malice reflected in pop music culture seek to promote a feminist ethic based on equality or on the difference of values?

The Spanish philosopher Celia Amorós, in her famous work Hacia una razón patriarcal (1985), stated that feminist ethics could not go down the route of positioning two types of ethics: the ethics of women against the ethics of men. For Amorós, this way of understanding ethics would correspond to the "feminism of difference" that, in turn, could be divided into US cultural feminism and the thinking of sexual difference. Focusing on US cultural feminism, she proposes a feminine counterculture, opposed to the patriarchal culture that praises the 
"feminine" values of tenderness, care, concern for others, the enemy of war, charitable, etc. Therefore, we would be looking at different values, and one might even talk about super positive qualities to male values because women, as mothers, are closer to nature (Moreno, 2011, p. 325). In this respect, it coincides more with the concept of the "third women", proposed by Lipovetsky.

The pop music industry appears to be conveying a feminism of equality. Women are not presented as weak; they do not need protection. They are self-sufficient and independent. And they assume that they are equal to men and have the right to enjoy "male" environments from which they have been excluded. They seem not to turn their gaze back to the "feminine" attributions assigned to them by the patriarchy, except when it comes to the continued use of the "fairer sex" label. But is this the path? Should we demand the right to malice?

My response is that there is a need to stop seeing the world as being divided in two: men and women. If malice in itself causes harm and creates suffering in the world, wouldn't it be better if it were rejected by men and women alike? These two clashing ethics need to merge. If caring for others, solidarity, the culture of peace, empathy... are values that help people to be "human", why can they not be adopted by men and women alike? Furthermore, neither women nor men are destined towards a certain path depending on our gender. We are free, independent beings. The primary purpose of women is not to be mothers or wives. They can choose to be or not, but the choice is theirs. Just as men are not destined by dint of obligation to be strong, independent, violent... That is why we believe that the response lies in education. The education system must ensure that values are not gendered. But it must also know how to choose which behaviours help people to become better in spite of the messages transmitted by the media.

A universal aesthetic for people is required that would make society a better place. There is a problem derived from the modern-day obsession with image and the values this imposes. We might even be witnessing a new type of discrimination based on physical appearance, associating beauty and a good physique with success and professional ability. Aesthetics determine morality in western society. Given this line of thinking, and its extremely negative consequences, how can we cope with the rapid influence of the media on post-modern society?

We advocate the need to analyse, evaluate and debate within education the values and counter-values promoted by pop music, through its music videos. As indicated by Alberoni (1963), there is a "powerless elite" —referring to music idols - that, together with religious, political and economic elites, influences the behaviour of the community (cfr. Busquet, 2012, p. 15). We cannot ignore their impact.

Currently, the Spanish education system barely tackles such an important issue as the pop music culture, which is so strongly present in the lives of the young generations, and which will determine the way in which society is constructed. We understand the difficulty of getting the media to change their messages, to reject the “stereotypical definitions” referred to by Marcela Lagarde (1990). Therefore, there might be other mechanisms, such as critical reflection through media and informational literacy, and methodologies such as service-learning ${ }^{1}$, which imply the commitment of students as responsible autonomous citizens who regard anything they consume visually with suspicion. The next step will be to tackle the issue of male malice/benignity among male pop singers.

\footnotetext{
${ }^{1}$ Currently, the Didactics Department of the Social Sciences Faculty at Malaga University, through a Teaching Innovation Project entitled "Application of the service-learning methodology in university teaching. Teaching innovation proposal for the civic education of teachers in the 21st Century", is developing service-learning projects aimed at tackling audiovisual contamination from the perspective of gender.
} 


\section{References}

Aguayo Torres, L. Á. (2012). Imagen artística e imagen publicitaria en la construcción de las identidades de género. Un proyecto de educación de personas adultas (Artistic image and advertising image in the construction of the gender identities. An education project of adult people). Universidad de Valladolid.

Amorós, C. (2007). La gran diferencia y sus pequeñas consecuencias...para las luchas de las mujeres (The small difference and its consequences). Madrid: Cátedra.

Amorós, C. (1985). Hacia una razón patriarchal (Towards a critique of patriarchal reason). Barcelona: Ed. Anthropos.

Araiza Díaz, A. (2008). Rescatando a las brujas. Hacia una contramemoria femenina (Rescuing female witches. Toward a counter feminine memory). Géneros. Revista de investigación y divulgación sobre los estudio de género (Genders. Journal of research on gender studies), 2, Period 2, Age 14, 61-79.

Ballester Maroto, M. (2013). La femme fatale en la publicidad del siglo XX. La popularización de un arquetipo decimonónico (La femme fatale in the publicity of the twentieth century. The popularization of the nineteenth-century archetype) (Doctoral thesis, University of Salamanca).

Busquet Duran, J. (2012). El fenómeno de los fans e ídolos mediáticos: evolución conceptual y génesis histórica. Jóvenes: ídolos mediáticos y nuevos valores (The phenomenon of fans and media idols: Conceptual evolution and historical genesis. Young people: Media idols and new values). Revista de Estudios de Juventud (Journal of Studies on Youth), 96, 13-29.

Novo, L. (2015). La imagen feminista de Taylor Swift, tildada de artificial (The feminist image of Taylor Swift, labelled as artificial). El País. Retrieved from http://www.elmundo.es/loc/2015/09/18/55f7ed1422601d322c8b4598.html

Haraway, D. (1984). Manifiesto Cyborg. El sueño irónico de un lenguaje común para las mujeres en el circuito integrado (A Cyborg Manifesto: Science, Technology, and Socialist-Feminism in the Late Twentieth Century). Retrieved from http://xenero.webs.uvigo.es/profesorado/beatriz_suarez/ciborg.pdf

Hidalgo-Marí, T. (2015). El resurgir de la mujer fatal en publicidad: la reinvención de un mito (The resurgence of the femme fatal in the publicity). Cuestiones de género: de la igualdad y la diferencia (Gender issues: The equality and the difference), 10, 394-418.

Hierro, G. (1992). La mujer y el mal (The woman and the evil). Isegoría, 6, 167-173.

Irigaray, L. (1992). Yo, tú, nosotras (Je, tu, nous: Towards a Culture of Difference). Madrid: Cátedra.

Lagarde, M. (1990). Identidad femenina (Female identity). Retrieved from http://www.hegoa.ehu.es/congreso/bilbo/doku/lau/IdentidadFemeninadeMarcelaLagarde.pdf

Lipovetsky, G., \& Serroy, J. (2015). La estetización del mundo. Vivir en la época del capitalismo artistic (The aestheticization of the world). Barcelona: Anagrama.

Lipovetsky, G. (1999). La tercera mujer (The third woman). Anagrama: Barcelona.

Manzano Espinosa, C. (2004). Relaciones entre heroínas y brujas. Relatos infantiles y juveniles en la literatura y el cine (Relationship between women heroines and witches. Childish tales in the literature and the film). Retrieved from http://www.baiona.org/c/document_library/get_file?uuid=7c5df5ca-e9d9-46bb-8251-18d325978b6a\&groupId=10904

Millet, K. (1969). Política sexual (Sexual politics). Madrid: Cátedra.

Morin, E. (1972). Las stars (The stars). Barcelona: Dopesa.

Ortega Balanza, M. (2015). La Reina de la Noche: la mala mujer, la mala madre (The Queen of the night: The bad woman, the bad mother). Arenal, 22: I, enero-junio, 91-120.

Ortiz Ibarz, J. M. (1988). La justificación del mal y el nacimiento de la estética. Leibniz y Baumgarten (The justice of the evil and the birth of the aesthetics. Leibniz and the Baumgarten). Anuario Filosófico (Philosophical Yearbook), 21, 151-157.

Puleo, A. H. (1997). Mujer, sexualidad y mal en la filosofía contemporánea (Woman, sexuality and evil in contemporary philosophy). Dainov, Revista de Filosofía (Dainov, Journal of Philosophy), 14, 167-172.

Rivière, M., (2009). La fama: iconos de la religión mediática (The fame: Religious and media icons). Crítica, Barcelona.

Rivière, M. (2009). Fama, medios de comunicación y opinión pública (Fame, mass media and public opinion). Quaderns del CAC (Cahiers of CAC), 33, 119-123.

Román Casas, Á. (2004). El hombre y su proyección en el cine contemporáneo (The man and his projection in the contemporary film). Estudio euroláser.

Valcárcel, A. (2010). Opinión pública, medios de comunicación e imagen: La ley del agrado (Public opinion, mass media and image: The law of attraction). Documentos de Trabajo (Working documents), 45, 85-135. 
Valcárcel, A. (2008). Entre la Venadita y la Medusa (Between La Venadita and the Medusa). Isegoría. Revista de FilosofíaMoral y Política (Isegoria. Journal of Moral Philosophy and Politics), 38, enero-junio, 2008, 101-118.

Valcárcel, A. (2004). El derecho a la maldad, entrevista realizada por Mariló Hidalgo (The right to malice, interviewed by Marilo Hidalgo). Revista Fusión (Merger Journal). Diciembre. $\quad$ Retrieved from http://www.revistafusion.com/2004/diciembre/entrev135.htm

Valcárcel, A. (1998). Sobre la verdad de la proposición "La ética y la estética son una” ("Ethics and aesthetics are one”). XII Congrés Valencià de Filosofia (XII Conference of Philosophy in Valencia). Valencia: Diputació de Valencia, 193-203.

Valcárcel, A. (1991). Sexo y filosofía (Sex and philosophy). Barcelona: Anthropos. 